\title{
AUDIT AWAL SISTEM E-LEARNING SKB GUNUNGKIDUL MENGGUNAKAN EMPAT DOMAIN PADA COBIT
}

\author{
Krisnawati $^{1)}$, Ema Utami ${ }^{2}$, Hartatik $^{3)}$, Hastari Utama ${ }^{4)}$ \\ ${ }^{1,2,3,4}$ STMIK AMIKOM Yogyakarta \\ ${ }^{1,3)}$ Manajemen Informatika STMIK AMIKOM Yogyakarta \\ ${ }^{2)}$ Magister Teknik Informatika STMIK AMIKOM Yogyakarta \\ ${ }^{4)}$ Sistem Informasi STMIK AMIKOM Yogyakarta \\ e-mail: *11krisna@amikom.ac.id, ${ }^{2}$ ema.u@ amikom.ac.id, ${ }^{3}$ utama@ amikom.ac.id, \\ hartatik@amikom.ac.id
}

\begin{abstract}
Abstrak
Pendidikan memiliki 3 bentuk yang berbeda berdasarkan formalitasnya yaitu pendidikan formal, nonformal dan informal.SKB Gunungkidul adalah salah satu penyelenggara pendidikan nonformal yang ada di Kabupaten Gunungkidul, Yogyakarta. Hasil analisa penyelenggaraan program kesetaraan kejar paket $C$ di SKB Gunung Kidul menggunakan diagram fishbone ditemukan ada enam masalah utama yaitu pendaftaran warga belajar, model pengajaran dan bahan ajar yang digunakan, penyelenggara pendidikan, model pembelajaran, model evaluasi, dan evaluasi mutu. Salah satu solusi dalam mengatasi permasalahan tersebut adalah dengan diselenggarakannya Pendidikan Jarak Jauh dengan pola e-learning.Namun sebelum diimplementasikan perlu dilakukan evaluasi guna evaluasi terhadap pengendalian sistem informasi e-learning ssehingga kegiatan operasional yang berkaitan dengan penyelenggaraan program pendidikan nonformal dapat berjalan dengan baik. Evaluasi dilakukan sesuai dengan standar COBIT dengan menggunakan empat domain yang ada di dalamnya yaitu Plan and Organise (PO), Acquire and Implement (AI), Deliver and Support (DS) dan Monitor and Evaluate (ME). Hasil perhitungan nilai maturity level pada masing-masing proses teknologi informasi didapatkan suatu nilai total PO sebesar 5.6, dan memiliki rata-rata PO sebesar 2.8, sehingga Gap yang didapatkan sebesar 0.70. hal tersebut menunjukan bahwa perencanaan dan perorganisasian cukup baik.
\end{abstract}

Kata kunci-Evaluasi, E-Learning, SKB Gunungkidul, COBIT

\begin{abstract}
Education has three different forms based on the formalities that formal education, nonformal and informal. Gunung SKB is one of the organizers of non-formal education in the district of Gunung Kidul, Yogyakarta. Results of analysis of the implementation of Packet $C$ equivalency program in SKB Gunung Kidul using fishbone diagrams found six main issues include registration of learners, teaching models and teaching materials used by students, education providers, learning model, the model of evaluation and quality evaluation. One solution to overcome the problem is with the convening of the Distance Education with the pattern of e-learning. But before it is implemented need to be evaluated in order to control e-learning information system so that operational activities related to the implementation of non-formal education programs can be run properly. Evaluation was conducted in accordance with the standard COBIT using four domains that are in it are Plan and Organise (PO), Acquire and Implement (AI), Deliver and Support (DS) and Monitor and Evaluate (ME). The result of the calculation of the value of maturity level for each process technology information obtained a total value of \$ $5.6 P O$ and PO has an average of 2.8 , so the Gap obtained amounted to 0.70. it shows that the planning and organization is quite well done.
\end{abstract}

Keywords-Evaluation, E-Learning, SKB Gunungkidul, COBIT

\section{PENDAHULUAN}


Pendidikan memiliki 3 bentuk yang berbeda berdasarkan formalitasnya (UU Nomor 20 Tahun 2003).Bentuk tersebut adalah pendidikan formal, nonformal dan informal.Pendidikan formal adalah jalur pendidikan yang terstruktur dan berjenjang yang terdiri atas pendidikan dasar, pendidikan menengah, dan pendidikan tinggi.Kemudian, pendidikan nonformal adalah jalur pendidikan di luar pendidikan formal yang dapat dilaksanakan secara terstruktur dan berjenjang.pendidikan informal adalah jalur pendidikan keluarga dan lingkungan. Ketiga pendidikan tersebut yang sering mendapat sorotan dan diwajibkan adalah pendidikan formal.

Pendidikan nonformal memiliki perbedaan dalam hal penyelenggaraannya.Pendidikan nonformal tidak diselenggarakan secara regular dan berkala mirip dengan pendidikan formal.Kegiatan belajar dari setiap siswanya difokuskan pada kemandirian belajarnya.Jadi, pengajar dan siswanya memiliki waktu yang sedikit dalam bertatap muka maka siswa harus lebih banyak belajar sendiri di rumah agar mampu memahami materinya.Selain itu, kurikulum yang ada disamakan sesuai dengan pendidikan formal tetapi tingkat kekomplekannya lebih rendah daripada pendidikan formal.Pendidikan nonformal diselenggarakan oleh berbagai lembaga pendidikan yang dari pemerintah.Salah satunya adalah Sanggar Kelompok Belajar (SKB).Keberadaan SKB di Indonesia tersebar ke berbagai daerah.SKB ini mempunyai tugas melaksanakan program kegiatan belajar luar sekolah, pemuda dan olahraga baik untuk sumber belajar (tutor, fasilitator) maupun untuk masyarakat.Bagi siswa yang putus sekolah atau tidak lolos dalam ujian nasional juga dapat melakukan ujian ulang atau melanjutkan di SKB ini karena terdapat paket penyetaraan dengan pendidikan formal.Paket tersebut adalah Kejar Paket A untuk penyetaraan tingkat SD, Kejar Paket B untuk penyetaraan tingkat SMP, serta Kejar Paket C untuk penyetaraan tingkat SMA [1].

Ciri khas dari pendidikan nonformal seperti yang diuraikan sebelumnya adalah minimnya tatap muka antara pendidik dengan siswanya [2].Setiap kabupaten hanya terdapat satu SKB.Hal ini menjadikan kendala bagi SKB saat menyelenggarakan aktifitas pendidikan. Salah satu SKB di daerah Gunung Kidul juga mengalami permasalahan ini.Wilayah Kabupaten Gunung Kidul yang terdiri dari bukit dan pegunungan, sertakendaraan umum dari pelosok daerah menuju ke SKB sangat terbatas membuat SKB Gunungkidul mengalami kesulitan dalam memantau proses belajar dari setiap siswanya. Salah satu solusi dalam mengatasi kendala SKB tersebut adalah dengan diselenggarakannya Pendidikan Jarak Jauh dengan pemanfaatan Internet.Menurut pengamatan dari SKB Gunung kidul bahwa akses masyarakat ke lokasi SKB terbatas tetapi penyebaran infrastruktur internet telah masuk ke daerah pelosok.Adanya prasarana untuk mengakses internet merupakan dukungan utama dalam menyelenggarakan Pendidikan JarakJauh.

Meskipun proses pembelajaran pendidikan jarak jauh dilakukan tanpa lewat antar muka secara langsung antara pengajar dan peserta didik, namun beberapa penelitian menunjukkan pola pembelajaran tetap mampu menghasilkan lulusan yang berkualitas. Seperti penelitian yang dilakukan oleh Hung, dkk (2009) yang berjudul "Effectiveness of Game-based Learning of a National Health e-Learning Network for Nutrition Education in Elementary School" [3].Penelitian ini mencoba untuk mempelajari pengaruh pembelajaran e-learning melalui edukasi games.Games ini mengajarkan pengetahuan tentang nutrisi ke siswa kelas 3 sekolah dasar.Hasilnya Proses evaluasi dilakukan dengan menghitung nilai tes siswa yang belajar melalui elearning dan pembelajaran konvensional.Hasilnya siswa dengan pola pembelajaran elearning memiliki nilai tes yang lebih baik.Penelitian lainnya dilakukan oleh Almekhlafi, dkk (2009) yang berjudul "An Evaluation Study of an e-Learning Course at the United Arab Emirates University: A Case Study" [4]. Penelitian ini dilakukan untuk melihat persepsi guru mengenai kegunaan dari metode elearning di kampus College of Education, Universitas Uni Emirat Arab.Peserta penelitian berjumlah 278 guru selama tahun akademik 2005-2006 dan 2006-2007. Hasil penelitian menunjukkan bahwa metode e-learning memiliki nilai kegunaan yang tinggi dalam proses pembelajaran.

Manfaat e-Learning yang begitu besar, membuat banyak institusi pendidikan yang mencoba untuk menerapkan konsep ini di metode pembelajaran yang dilakukan.Namun sebelum dilakukan penerapan perlu adanya analisa pola e-Learning yang tepat untuk bisa diimplementasikan di SKB Gunungkidul.Model e-Learning yang diterapkan oleh Rienties Bart pada tahun 2015 dan ditulis pada paper yangberjudul, "Scaling up" learning design: impact of learning design activities on LMS behavior and performance membahas mengenaipenerapan LAK 
(Learning Analytics Knowledge) untuk mengukur korelasi antara pengelolaan Learning Management System (LMS) dengan tingkat performa belajar yang dimiliki oleh peserta didik [5]. Hasil dari pengclusteran analisis ditemukan suatu pola desain pembelajaran yang memiliki empat pola, yaitu constructivist, assessment-driven, balanced-variety dan social constructivist modules.Jika cluster analisis ini diterapkan di SKB Gunungkidul masih kurang tepat dilakukan. Penyebabnya karena terdapat aspek-aspek lain yang berpengaruh pada pola pembelajaran peserta didik SKB Gunungkidul yang belum dianalisis seperti desain pembelajaran yang meliputi konteks, karakteristik pembelajar, modul dan kebijakan instansi.Model e-Learning lainnya yang diterapkan oleh Zheng Saijing pada tahun 2015 dan ditulis di paper dengan judul "Understanding Student Motivation, Behaviors, and Perceptions in MOOCs" berfokus pada alasan kegagalan peserta didik dalam mengikuti pola pembelajaran e-learning [6]. Hasil dari penelitian yang dilakukan oleh Zheng menunjukkan bahwa motivasi pembelajar, gaya belajar dan pola belajar peserta didik memiliki pengaruh besar pada pada sukses dan tidaknya penerapan e-learning. Kekurangan dari penelitian yang dilakukan oleh Zheng adalah adanya keterbatasan rentan usia peserta didik, dan keterbatasan wilayah geografis yang bisa membuat terjadinya perbedaan gaya belajar dan motivasi peserta didik.

\section{METODE PENELITIAN}

Tahapan penelitian yang akan dilakukan terdiri dari enam tahapan yaitu business understanding, tinjauan pustaka, analisis data, penyusunan rencana kerja evaluasi, analisis menggunakan COBIT, dan yang terakhir adalah perhitungan nilai maturitylevel. Tahapan ini digambarkan di gambar 2.1.

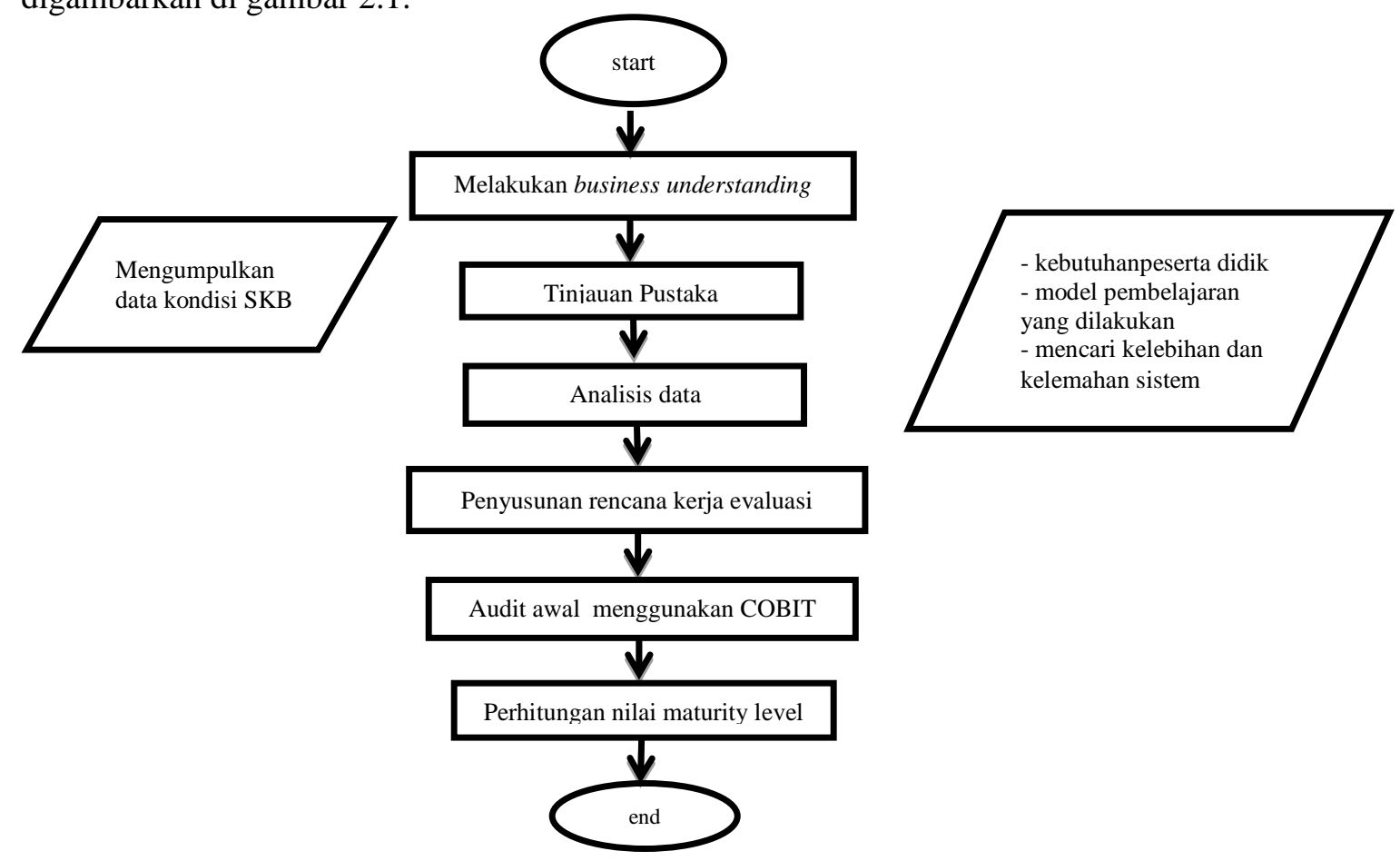

Gambar 1. Kerangka berfikir penelitian

Penjelasan dari masing-masing tahapan yang ada di gambar 2.1 adalah :

1. Business Understanding : meliputi penentuan tujuan bisnis, menilai situasi saat ini, menetapkan tujuan, dan mengembangkan rencana proyek penyelenggaraan pembelajaran jarak jauh kejar paket C di SKB Gunung Kidul.

2. Tinjauan Pustaka :Pada tahapan ini dilakukan studi literatur dan kajian pustaka terhadap beberapa referensi yang relevan dengan topik penelitian. Adapun referensi yang dirujuk dalam penelitian ini adalah pendidikan nonformal, konsep kejar paket B dan C, E-Learning, serta learning distance. 
3. Analisis data :Tahap ini dilakukan dengan mempelajari dan memahami domain masalah untuk analisis keseluruhan masalah, peluang, dan batasan. Tahapan analisis terdiri atas analisis permasalahan dan pemecahannya berdasarkan referensi pada tahapan sebelumnya. Hasil dari analisa sistem adalah diagram fishbone.

4. Penyusunan rencana kerja evaluasi. Pada tahapan ini dilakukan proses evaluasi pengendalian sistem informasi e-learning sesuai dengan standar COBIT dan empat domain yang ada di dalamnya.

5. Melakukan audit awal menggunakan COBIT. Audit awal ini bertujuan untuk mendapatkan temuan-temuan permasalahan yang ada pada pelaksanaan kejar paket C di SKB Gunung Kidul. Temuan masalah yang ada tersebut akan dijadikan identifikasi masalah untuk menentukan solusi yang tepat dalam mengatasinya menggunakan teknologi informasi. Jadi, penentuan teknologi informasi yang sesuai untuk permasalahan penyelenggaraan pembelajaran tersebut dapat menjadi efektif. Rencana audit awal ini menggunakan kerangka kerja COBIT

6. Perhitungan nilai maturity level.

\section{HASIL DAN PEMBAHASAN}

Model pembelajaran program kesetaraan kejar paket C di SKB Gunung Kidul masihberpusat pada pendidik sebagai pihak pengelola pembelajaran. Proses pembelajaran masih dilakukan secara konvensional melalui tatap muka. Materi yang diberikan masih bersifat teoritis, dan belum bisa merelasikan dengan manfaat teori tersebut di dunia nyata atau dunia kerja.Hal lainnya yang membuat program kejar paket $\mathrm{C}$ kurang berkembang adalah kurangnya jumlah pengajar program kesetaraan di SKB Gunung Kidul. Hingga saat ini, SKB Gunung Kidul baru memiliki 7 orang pengajar dengan kualifikasi pendidikan Ekonomi, Sosiologi, Bahasa Inggris, Bahasa Indonesia, Matematika, dan PKn. Beberapa mata pelajaran seperti diluar mata pelajaran tersebut belum memiliki pengajar. Akibatnya sering terjadi suatu kasus dimana pengajar yang mengajar suatu matapelajaran bukanlah orang yang kompetensinya di bidang tersebut. Metode pembelajaran yang dilakukan pengajar didalam kelas adalah metode menerangkan materi kepada warga belajar dengan diselingi beberapa pertanyaan. Metode seperti ini dirasa kurang efektif mengingat keterbatasan waktu dan letak geografis masing-masing peserta didik.Hal ini dapat dilihat pada saat proses KBM berlangsung, hanya sedikit dari warga belajar yang hadir. Selain faktor sumber daya manusia dan metode belajar mengajar yang masih konvensional, masalah lain yang terdapat dalam penyelenggaraan pendidikan kesetaraan paket $C$ di UPT SKB Gunungkidul adalah kurangnya ketersediaan fasilitas dalam proses belajar mengajar. UPT SKB Gunungkidul belum memiliki ruang untuk pelaksanaan program paket $\mathrm{C}$.

Dari hasil pengumpulan datadidapatkan fakta bahwa dalam penyelenggaraan pendidikan kesetaraan di SKB Gunungkidul ditemukan ada enam masalah utama yaitu pendaftaran warga belajar , model pengajaran dan bahan ajar yang digunakan (meliputi metode pembelajaran, pengembangan kurikulum, dan penggunaan media belajar yang bisa digunakan oleh warga belajar), penyelenggara pendidikan, model pembelajaran, model evaluasi, dan evaluasi mutu.Permasalahan ini digambarkan pada gambar 2. 


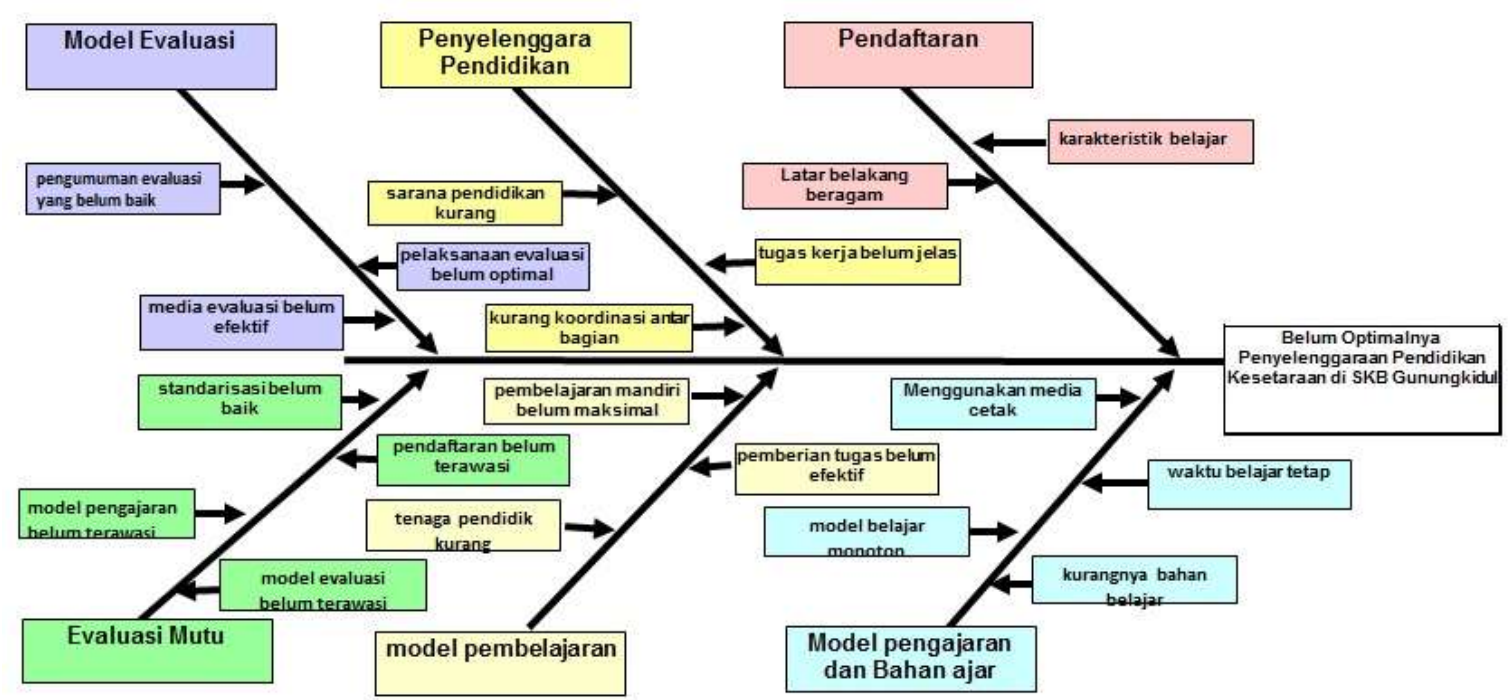

Gambar 2. Diagram fishbone pembelajaran di SKB Gunungkidul

Salah satu solusi yang coba diterapkan untuk menyelesaikan masalah pembelajaran di SKB Gunungkidul adalah penerapan e-learning yang dapat membantu peserta didik dalam kegiatan registrasi, belajar mengajar maupun kegiatan evaluasi.Evaluasi terhadap pengendalian sistem informasi e-learning sangat memiliki peranan yang sangat penting.Hal ini karena segala kegiatan operasional yang berkaitan dengan penyelenggaraan program pendidikan nonformal dapat berjalan dengan baik. Evaluasi ini akan membuat rencana kerja, dimana data yang diperoleh melalui wawancara, observasi dan checklist. rencana kerja yang akan dilakukan dapat dilihat pada tabel 1 .

Tabel 1. Rencana kerja evaluasi

\begin{tabular}{|c|c|c|}
\hline Aktivitas & Data yang dikumpulkan & Metode \\
\hline $\begin{array}{l}\text { Melakukan survey/observasi terhadap lokasi } \\
\text { yang akan digunakan dalam penelitian ini }\end{array}$ & $\begin{array}{l}\text { Mendapatkan lokasi penelitian dan evaluasi } \\
\text { terhadap sistem informasi e-learning }\end{array}$ & $\begin{array}{l}\text { Observasi } \\
\text { Wawancara }\end{array}$ \\
\hline $\begin{array}{l}\text { Menentukan ruang lingkup pembahasan, } \\
\text { metodologi dan sistematika penulisannya, } \\
\text { serta menentukan landasan teori dalam } \\
\text { mendukung pada proses penelitian ini. }\end{array}$ & $\begin{array}{l}\text { Mendapatkan ruang lingkup } \\
\text { pembahasan yang sesuai dan } \\
\text { landasan teori yang berhubungan dengan topik } \\
\text { yang akan dibahas dalam penelitian ini }\end{array}$ & $\begin{array}{l}\text { Observasi } \\
\text { Studi } \\
\text { Pustaka } \\
\text { Penelitian } \\
\text { sebelumnya }\end{array}$ \\
\hline Meminta dan menganalisis profil instansi & $\begin{array}{l}\text { Mendapatkan profilinstansipada lembaga } \\
\text { penyelenggaran pendidikan nonformal } \\
\text { yang terdiri dari struktur organisasi beserta tugas } \\
\text { dan tanggung jawab dan proses e-learning yang } \\
\text { sedang berjalan saat ini }\end{array}$ & $\begin{array}{l}\text { Observasi } \\
\text { Wawancara } \\
\text { Checklist }\end{array}$ \\
\hline $\begin{array}{l}\text { Meminta dan menganalisa arsitektur } \\
\text { sistem informasi e-learning yang digunakan }\end{array}$ & $\begin{array}{l}\text { Mendapatkan gambaran dari sistem informasi e- } \\
\text { learning yang berjalan termasuk spesifikasi } \\
\text { hardware, software,networkdan database dan print } \\
\text { screen user interface dari sistem yang berjalan. }\end{array}$ & $\begin{array}{l}\text { Observasi } \\
\text { Wawancara }\end{array}$ \\
\hline $\begin{array}{l}\text { Membuat daftar pertanyaan yang akan } \\
\text { diajukan kepada penanggungjawab pada } \\
\text { tujuan instansi yang akan } \\
\text { dievaluasi }\end{array}$ & $\begin{array}{l}\text { Mendapatkan jawaban atas } \\
\text { pertanyaan yang diajukan }\end{array}$ & Checklist \\
\hline $\begin{array}{l}\text { Melakukan evaluasi pengendalian sistem } \\
\text { yang digunakan serta analisis dan } \\
\text { perhitungan maturity model berdasarkan } \\
\text { jawaban yang diberikan }\end{array}$ & $\begin{array}{l}\text { Mendapatkan hasil perhitungan dari penentuan } \\
\text { level maturity dan hasilevaluasi pengendalian } \\
\text { tersebutbeserta laporan }\end{array}$ & $\begin{array}{l}\text { Observasi } \\
\text { Wawancara } \\
\text { Checkliat }\end{array}$ \\
\hline $\begin{array}{l}\text { Menemukan temuan dan menentukan } \\
\text { rekomendasi sebagai usulan perbaikan } \\
\text { terhadap sistem informasi e-learning pada } \\
\text { pendidikan nonformal }\end{array}$ & $\begin{array}{l}\text { Menghasilkan rekomendasi atas temuan yang tidak } \\
\text { sesuai standar operasional atau kegiatan yang } \\
\text { merugikan lembaga }\end{array}$ & $\begin{array}{l}\text { Analisis } \\
\text { data }\end{array}$ \\
\hline Membuat Laporan Evaluasi & $\begin{array}{l}\text { Hasil evaluasi yang dilakukan beserta temuan dan } \\
\text { rekomendasi yang diusulkan }\end{array}$ & $\begin{array}{l}\text { Analisis } \\
\text { Data }\end{array}$ \\
\hline
\end{tabular}


Ruang lingkup evaluasi pengendalian pada sistem informasi e-learning yang akan diteliti dibatasi pada :

1. Mengevaluasi pengendalian sistem informasi e-learning

2. Mengevaluasi pengendalian sistem informasi e-learning sesuai dengan standar COBIT dan empat domain yang ada di dalamnya, berikut ini beberapa indikator pada empat domain yang akan diteliti, meliputi:

a. Plan and Organise (PO)

PO4 Mendefinisikan Proses IT, Orgnisasi dan Kerjasama.

PO4.1 Kerangka Kerja Proses TI

PO4.2 Komite Strategis TI

PO4.3 Komite TI

PO4.4 Penepatan Organisasi dari Fungsi TI

PO4.5 Struktur Organisasi TI

PO4.6 Membuat Peran dan Tanggung Jawab

PO4.7 Tanggung Jawab untuk Memastikan Kualitas TI

PO4.8 Tanggung Jawab dalam Resiko Keamanan dan Pemenuhan

PO4.9 Kepemilikan Data dan Sistem

PO4.10 Pengawasan

PO4.11 Pemisahan Tugas

PO4.12 Kepegawaian TI

PO4.13 Personel Inti TI

PO4.14 Kebijakan dan Prosedur Pegawai Kontrak

PO4.15 Hubungan

PO7 Mengelola SDM IT

PO7.1 Perekrutan dan Penahanan Personel

PO7.2 Kompetensi Personel

PO7.3 Pemilihan Pegawai Peran

PO7.4 Pelatihan Personel

PO7.5 Ketergantungan Antar Individu

PO7.6 Prosedur Pembersihan Personel

PO7.7 Evaluasi Performansi Kerja Pegawai

PO7.8 Perubahan dan Pemberhentian Kerja

b. Acquire and Implement (AI)

AI3 Memperoleh dan Memelihara Infrastruktur

AI3.1 Rencana Akuisisi Infrastruktur Teknologi

AI3.2 Proteksi Infrastruktur Sumber Daya dan Ketersediaan

AI3.3 Pemeliharaan Infrastruktur

AI3.4 Lingkup Uji Kelayakan

AI4 Mengembangkan operasional dan penggunaannya

AI4.1 Perencanaan untuk Pemecahan Masalah Operasional

AI4.2 Pemindahan Ilmu pada Manajemen Instansi

AI4.3 Pemindahan Ilmu pada Pemakai Akhir

AI4.4 Pemindahan Ilmu pada Pegawai Pendukung dan Operasi

AI6 Mengelola Perubahan

AI6.1 Standar dan Prosedur Perubahan

AI6.Penilaian, Prioritisasi dan Kewenangan Dampak

AI6.3 Perubahan Darurat

AI6.4 Penelusuran dan Pelaporan Status Perubahan

AI6.5 Penutupan dan Dokumentasi Perubahan

c. Deliver and Support (DS)

DS5 Menjamin Keamanan Sistem

DS5.1 Manejemen Keamanan TI

DS5.2 Rencana Keamanan TI

DS5.3 Indentifikasi Manejemen 
DS5.4 Manejemen Rekening Pemakai

DS5.5 Pengujian Keamanan, Pengawasan dan Pengamatan

DS5.6 Definisi Kejadian Keamanan

DS5.7 Penjaga Teknologi Keamanan

DS5.8 Menejemen Kunci Cryptographic

DS5.9 Pencegahan, Deteksi dan Koreksi Terhadap Software Berbahaya

DS5.10 Keamanan Jaringan

DS5.11 Petukaran Data yang Sensitif

DS6 Mengidentifikasi dan mengalokasikan biaya

DS6.1 Definisi Service

DS6.2 Akuntansi IT

DS6.3 Biaya Pemodelan dan Pembebanan

DS6.4 Pemeliharaan Biaya Model

DS7 Pendidikan dan Pelatihan

DS7.1 Identifikasi Kebutuhan Pendidikan dan Pelatihan

DS7.2 Penyaluran Pelatihan dan Pendidikan

DS7.3 Evaluasi Pelatihan yang Diterima

DS8 Menangani Insiden dan Pelayanan

DS8.1 Bagian Layanan

DS8.2 Pendaftaran Keraguan Pelanggan

DS8.3 Kenaikan Insiden

DS8.4 Penutupan Insiden

DS8.5 Pelaporan dan Analisis Tren

d. Monitor and Evaluate (ME)

ME1 Mengawasi dan Mengevaluasi Kinerja IT

ME1.1 Pendekatan Pengawasan

ME1.2 Definisi dan Kumpulan dari Data Pengawasan

ME1.3 Metode Pengawasan

ME1.4 Perkiraan Pencapaian

ME1.5 Laporan Eksekutif dan Dewan

ME1.6 Tindakan Pembetulan

ME2 Memantau serta mengevaluasi kontrol internal

ME 2.1 Memantau pengendalian internal

ME 2.2 Penilaian manager IT internal

ME 2.3 Pengendalian kesalahan mendasar

ME 2.4 Pengendalian diri berkesinambungan

ME 2.5 Jaminan pengendalian internal

3. Berdasarkan COBIT 4.1, analisis perspektif yang digunakan dalam mengevaluasi pengendalian sistem informasi e-learning.

Dari hasil pengamatan yang telah dilakukan terhadap sistem informasi telah berjalan secara online tetapi belum terintegrasi dengan baik dan belum dimanfaatkan secara optimal penggunaan system tersebut. Layanan sistem informasi memiliki beberapa aktifitas yang sistem informasi komputer guna mendukung tujuan tersebut yaitu :

1. Beranda. Berisi tentang berita atau informasi terkini tentang pendidikan nonformal, serta pengumuman yang berkaitan dengan pendidikan nonformal.

2. Profil. Data ini berisi tentang pendidikan nonformal, struktur organisasi dan ketenagaan pada dinas pendidikan nonformal.

3. Program. Berisi tentang bagian dari Pendidikan Nonformal dan Informal yang menyelanggarakan pendidikan umum mencakup program Paket A Setara SD/MI, Paket B Setara SMP/MTS, dan Paket C Setara SMA/MA.

4. E-learning. Berisi tentang materi pembelajaran pada pendidikan nonformal.

Hasil dari pengamatan berdasarkan key performace indicator digambarkan pada tabel 2 .

Tabel 2. Tabel Key Performa Indicator saat ini

\begin{tabular}{|l|l|l|l|l|l|}
\hline No & Perspektif & Tujuan & KPI & Pengukuran & Nila \\
\hline
\end{tabular}


Krisnawati, Audit Awal Sistem E-Learning...63

\begin{tabular}{|c|c|c|c|c|c|}
\hline & & & & & i \\
\hline 1 & $\begin{array}{l}\text { Kapasitas } \\
\text { bangunan }\end{array}$ & $\begin{array}{l}\text { Sinergi } \\
\text { pendidikan }\end{array}$ & $\begin{array}{ll}\text { Kelas dan } \\
\text { kapasitas }\end{array}$ & $\begin{array}{l}\text { 0: } \text { siswa }>\text { kapasitas } \\
\text { 1: siswa }=\text { kapasitas } \\
\text { 2: siswa }<\text { kapasitas }\end{array}$ & 1 \\
\hline 2 & IT & Kinerja infrastruktur & $\begin{array}{l}\text { Komputer } \\
\text { infrastruktur }\end{array}$ & $\begin{array}{l}0: \text { tidak ada } \\
\text { 1: ada } \\
\text { 2: baik }\end{array}$ & 0 \\
\hline 3 & IT & Standarisasi Hardware & $\begin{array}{l}\text { Hardware } \\
\text { komputer }\end{array}$ & $\begin{array}{l}0: \text { tidak ada } \\
\text { 1: ada } \\
\text { 2: baik }\end{array}$ & 0 \\
\hline 4 & IT & Standarisasi software & $\begin{array}{l}\text { Standarisasi } \\
\text { software }\end{array}$ & $\begin{array}{l}0: \text { tidak ada } \\
\text { 1: ada } \\
\text { 2: baik }\end{array}$ & 1 \\
\hline 5 & IT & Minimasi masalah komputer & $\begin{array}{l}\text { Masalah } \\
\text { komputer }\end{array}$ & $\begin{array}{l}0: \text { tidak ada } \\
\text { 1: ada } \\
\text { 2: baik }\end{array}$ & 1 \\
\hline 6 & IT & Pegawaif IT yang baik & $\begin{array}{l}\text { Laboratorium } \\
\text { komputer }\end{array}$ & $\begin{array}{l}0: \text { tidak ada } \\
\text { 1: ada } \\
\text { 2: baik }\end{array}$ & 1 \\
\hline 7 & IT & Keamanan jaringan internet & $\begin{array}{l}\text { Keamanan } \\
\text { jaringan }\end{array}$ & $\begin{array}{l}0 \text { : tidak ada } \\
\text { 1: ada } \\
\text { 2: baik }\end{array}$ & 0 \\
\hline 8 & IT & Keamanan jaringan internet & $\begin{array}{lr}\text { Keamanan } & \\
\text { internet } & \text { bagi } \\
\text { dosen } & \text { dan } \\
\text { pegawaif } & \end{array}$ & $\begin{array}{l}0 \text { : tidak ada } \\
\text { 1: ada } \\
\text { 2: baik }\end{array}$ & 0 \\
\hline 9 & IT & Pemanfaatan teknologi & $\begin{array}{l}\text { Pelatihan } \\
\text { software }\end{array}$ & $\begin{array}{l}\text { 0: tidak ada } \\
\text { 1: ada } \\
\text { 2: baik }\end{array}$ & 1 \\
\hline 10 & IT & Pemanfaatan teknologi & $\begin{array}{l}\text { Pelatihan } \\
\text { keamanan } \\
\text { internet }\end{array}$ & $\begin{array}{l}0: \text { tidak ada } \\
\text { 1: ada } \\
\text { 2: baik }\end{array}$ & 1 \\
\hline 11 & Akademik & Pengembangan pengajaran & Kehadiran guru & $\begin{array}{l}0: \text { tidak ada } \\
1 \text { : ada } \\
2 \text { : baik }\end{array}$ & 0 \\
\hline 12 & Akademik & Pengembangan kepuasan siswa & $\begin{array}{l}\text { Update nilai } \\
\text { siswa }\end{array}$ & $\begin{array}{l}0: \text { terlambat } \\
1: \text { deadline } \\
2: \text { sebelum deadline }\end{array}$ & 2 \\
\hline 13 & akademik & Pengembangan kepuasan siswa & $\begin{array}{ll}\text { Update } & \text { jadwal } \\
\text { belajar, } & \text { jadwal } \\
\text { ujian } & \end{array}$ & $\begin{array}{l}0: \text { terlambat } \\
1: \text { deadline } \\
\text { 2:sebelum deadline }\end{array}$ & 2 \\
\hline 14 & Perpustakaan & Pengembalian & $\begin{array}{l}\text { Pengembalian } \\
\text { tepat waktu }\end{array}$ & $\begin{array}{l}0: \text { terlambat } \\
1: \text { deadline } \\
\text { 2:sebelum deadline }\end{array}$ & 2 \\
\hline
\end{tabular}

Masing-masing bobot dari nilai nilai pemenuhan tersebut menunjukan tingkat persetujuan terhadap satu pernyataan, seperti tertera pada tabel 3 .

Tabel 3. Tingkat persetujuan pada suatu pernyataan

\begin{tabular}{|l|l|}
\hline Aggrement with statement & Compliance Value \\
\hline Not at all & 0 \\
\hline A Little & 0.33 \\
\hline Quite a Lot & 0.66 \\
\hline Completely & 1 \\
\hline
\end{tabular}

Setelah dilakukan proses pengumpulan data dengan kuesioner, diperoleh hasil perhitungan untuk setiap proses IT berdasarkan maturity level. Hasil perhitungan dapat dilihat pada tabel 4 sampai dengan tabel 4.

Tabel 4. Hasil Perhitungan PO04 untuk Maturity Level 0-5

\begin{tabular}{|c|c|c|c|c|c|}
\hline $\begin{array}{c}\text { Maturity } \\
\text { Level }\end{array}$ & $\begin{array}{c}\text { Sum ofStatements } \\
\text { ComplianceValues }\end{array}$ & $\begin{array}{c}\text { Number } \\
\text { ofMaturityLevel }\end{array}$ & $\begin{array}{c}\text { MaturityLevel } \\
\text { ComplianceValue }\end{array}$ & $\begin{array}{c}\text { NormalizedCompliance } \\
\text { Values }\end{array}$ & $\begin{array}{c}\text { Contribution } \\
{[\mathrm{M}] \mathrm{x}[\mathrm{D}]}\end{array}$ \\
\hline
\end{tabular}




\begin{tabular}{|l|l|l|l|l|l|}
\hline \multicolumn{1}{|c|}{$[\mathbf{M}]$} & \multicolumn{1}{c|}{$\begin{array}{c}\text { Statements } \\
{[\mathbf{B}]}\end{array}$} & \multicolumn{1}{c|}{$[\mathbf{A} / \mathbf{B}]=[\mathbf{C}]$} & {$[\mathbf{C} / \mathbf{s u m} \mathbf{C}]=[\mathbf{D}]$} \\
\hline 0 & 0.99 & 2.00 & 0.50 & 0.16 & 0.00 \\
\hline 1 & 0.99 & 2.0 & 0.50 & 0.16 & 0.16 \\
\hline 2 & 0.33 & 0.33 & 0.11 & 0.22 \\
\hline 3 & 1.65 & 3.00 & 0.55 & 0.18 & 0.54 \\
\hline 4 & 5.29 & 9.00 & 0.59 & 0.19 & 0.77 \\
\hline 5 & 6.93 & 12.00 & 0.19 & 0.95 \\
\hline
\end{tabular}

Tabel 5. Hasil Perhitungan PO07 untuk Maturity Level 0-5

\begin{tabular}{|c|c|c|c|c|c|}
\hline $\begin{array}{l}\text { Maturity } \\
\text { Level } \\
{[\mathrm{M}]}\end{array}$ & $\begin{array}{c}\text { Sum of Statements } \\
\text { Compliance Values } \\
\text { [A] }\end{array}$ & $\begin{array}{c}\text { Number } \\
\text { ofMaturityLevel } \\
\text { Statements } \\
{[\mathrm{B}]}\end{array}$ & $\begin{array}{c}\text { MaturityLevel } \\
\text { Compliance Value } \\
{[\mathrm{A} / \mathrm{B}]=[\mathrm{C}]}\end{array}$ & $\begin{array}{c}\text { NormalizedCompliance } \\
\text { Values } \\
{[\mathrm{C} / \mathrm{sum} \mathrm{C}]=[\mathrm{D}]}\end{array}$ & $\begin{array}{c}\text { Contribution } \\
{[\mathrm{M}] \times[\mathrm{D}]}\end{array}$ \\
\hline $\mathbf{0}$ & 0.33 & 1.00 & $\mathbf{0 . 3 3}$ & 0.11 & 0.00 \\
\hline 1 & 0.33 & 1.00 & 0.33 & 0.11 & 0.11 \\
\hline 2 & 0.66 & 1.00 & 0.66 & 0.22 & 0.44 \\
\hline 3 & 0.33 & 1.00 & $\mathbf{0 . 3 3}$ & 0.11 & $\mathbf{0 . 3 3}$ \\
\hline 4 & 2.64 & 4.00 & 0.66 & 0.22 & 0.88 \\
\hline \multirow[t]{2}{*}{5} & 5.63 & 8.00 & $\mathbf{0 . 7 0}$ & 0.23 & 1.17 \\
\hline & & & 3.01 & 1.00 & 2.92 \\
\hline
\end{tabular}
diterapkan

Tabel 6. Hasil Perhitungan AI3 untuk Maturity Level 0-5

\begin{tabular}{|c|c|c|c|c|c|}
\hline $\begin{array}{l}\text { Maturity } \\
\text { Level } \\
{[\mathrm{M}]}\end{array}$ & $\begin{array}{c}\text { Sum of Statements } \\
\text { Compliance Values } \\
\text { [A] }\end{array}$ & $\begin{array}{c}\text { Number } \\
\text { ofMaturityLevel } \\
\text { Statements } \\
{[\mathrm{B}]}\end{array}$ & $\begin{array}{c}\text { MaturityLevel } \\
\text { Compliance Value } \\
{[\mathrm{A} / \mathrm{B}]=[\mathrm{C}]}\end{array}$ & $\begin{array}{c}\text { NormalizedCompliance } \\
\text { Values } \\
{[\mathrm{C} / \mathrm{sum} \mathrm{C}]=[\mathrm{D}]}\end{array}$ & $\begin{array}{c}\text { Contribution } \\
{[\mathrm{M}] \times[\mathrm{D}]}\end{array}$ \\
\hline 0 & 0.33 & 1.00 & 0.33 & 0.17 & 0.00 \\
\hline 1 & 0.66 & 2.00 & 0.33 & 0.17 & 0.17 \\
\hline 2 & 0.00 & 0.00 & 0.00 & 0.00 & 0.00 \\
\hline 3 & 2.64 & 4.00 & 0.66 & 0.33 & 1.00 \\
\hline 4 & 1.32 & 4.00 & 0.33 & 0.17 & 0.67 \\
\hline \multirow[t]{2}{*}{5} & 1.65 & 5.00 & 0.33 & 0.17 & 0.83 \\
\hline & & & 1.98 & 1.00 & 2.67 \\
\hline
\end{tabular}

Tabel 7. Hasil Perhitungan AI4 untuk Maturity Level 0-5

\begin{tabular}{|l|l|l|l|l|l|}
\hline $\begin{array}{c}\text { Maturity } \\
\text { Level } \\
{[\mathrm{M}]}\end{array}$ & $\begin{array}{c}\text { Sum ofStatements } \\
\text { ComplianceValues } \\
{[\mathrm{A}]}\end{array}$ & $\begin{array}{c}\text { Number } \\
\text { ofMaturityLevel } \\
\text { Statements } \\
{[\mathbf{B}]}\end{array}$ & $\begin{array}{c}\text { MaturityLevel } \\
\text { ComplianceValue } \\
{[\mathbf{A} / \mathbf{B}]=[\mathbf{C}]}\end{array}$ & $\begin{array}{c}\text { NormalizedCompliance } \\
\text { Values } \\
{[\mathbf{C} / \text { sum C]= }[\mathbf{D}]}\end{array}$ & $\begin{array}{c}\text { Contribution } \\
{[\mathrm{M}] \mathbf{x}[\mathbf{D}]}\end{array}$ \\
\hline 0 & 0.33 & 1.00 & 0.33 & 0.18 & 0.00 \\
\hline 1 & 0.00 & 0.00 & 0.00 & 0.00 & 0.00 \\
\hline 2 & 0.00 & 0.00 & 0.00 & 0.00 & 0.00 \\
\hline 3 & 0.99 & 3.00 & 0.33 & 0.18 & 0.54 \\
\hline 4 & 2.64 & 4.00 & 0.66 & 0.36 & 1.45 \\
\hline 5 & 0.99 & 2.00 & 1.82 & 0.27 \\
\hline
\end{tabular}

Tabel 8. Hasil Perhitungan AI6 untuk Maturity Level 0-5

\begin{tabular}{|c|c|c|c|c|c|}
\hline $\begin{array}{l}\text { Maturity } \\
\text { Level } \\
{[M]}\end{array}$ & $\begin{array}{c}\text { Sum of Statements } \\
\text { Compliance Values } \\
{[A]}\end{array}$ & $\begin{array}{c}\text { Number } \\
\text { ofMaturityLevel } \\
\text { Statements } \\
{[B]}\end{array}$ & $\begin{array}{c}\text { MaturityLevel } \\
\text { ComplianceValue } \\
{[A / B]=[C]}\end{array}$ & $\begin{array}{c}\text { NormalizedCompliance } \\
\text { Values } \\
{[\text { C/sum } C]=[D]}\end{array}$ & $\begin{array}{c}\text { Contribution } \\
{[M] x[D]}\end{array}$ \\
\hline 0 & 0.00 & 0.00 & 0.00 & 0.00 & 0.00 \\
\hline 1 & 0.00 & 0.00 & 0.00 & 0.00 & 0.00 \\
\hline 2 & 2.31 & 5.00 & 0.46 & 0.22 & 0.44 \\
\hline 3 & 0.66 & 1.00 & 0.66 & 0.32 & 0.95 \\
\hline 4 & 1.65 & 3.00 & 0.55 & 0.26 & 1.06 \\
\hline
\end{tabular}


Krisnawati, Audit Awal Sistem E-Learning...65

\begin{tabular}{|c|c|c|c|c|c|}
\hline 5 & 1.65 & 4.00 & 0.41 & 0.20 & 0.99 \\
\hline & & & 2.08 & 1.00 & 3.45 \\
\hline
\end{tabular}

Maturity level berada pada level 3, hal ini berarti prosedur telah distandarisasi, didokumentasikan, dan dikomunikasikan dan instansi telah mulai mengenai metodologi pengembangan sistem, namun belum adanya pengawasan dari pihak manajemen.

Tabel 9. Hasil Perhitungan DS5 untuk Maturity Level 0-5

\begin{tabular}{|c|c|c|c|c|c|}
\hline $\begin{array}{c}\text { Maturity } \\
\text { Level } \\
{[M]}\end{array}$ & $\begin{array}{c}\text { Sum of Statements } \\
\text { ComplianceValues } \\
{[A]}\end{array}$ & $\begin{array}{c}\text { Number } \\
\text { ofMaturityLevel } \\
\text { Statements } \\
{[B]}\end{array}$ & $\begin{array}{c}\text { MaturityLevel } \\
\text { Compliance Value } \\
{[A / B]=[C]}\end{array}$ & $\begin{array}{c}\text { NormalizedCompliance } \\
\text { Values } \\
{[\text { C/sum } C]=[D]}\end{array}$ & $\begin{array}{c}\text { Contribution } \\
{[M] x[D]}\end{array}$ \\
\hline 0 & 0.66 & 2.00 & 0.33 & 0.19 & 0.00 \\
\hline 1 & 0.00 & 0.00 & 0.00 & 0.00 & 0.00 \\
\hline 2 & 0.00 & 0.00 & 0.00 & 0.00 & 0.00 \\
\hline 3 & 0.66 & 2.00 & 0.33 & 0.19 & 0.57 \\
\hline 4 & 3.63 & 7.00 & 0.52 & 0.30 & 1.19 \\
\hline \multirow[t]{2}{*}{5} & 8.58 & 15.00 & 0.57 & 0.33 & 1.63 \\
\hline & & & 1.75 & 1.00 & 3.39 \\
\hline
\end{tabular}

Tabel 10. Hasil Perhitungan DS6 untuk Maturity Level 0-5

\begin{tabular}{|c|c|c|c|c|c|}
\hline $\begin{array}{l}\text { Maturity } \\
\text { Level } \\
{[M]}\end{array}$ & $\begin{array}{c}\text { Sum of Statements } \\
\text { Compliance Values } \\
\qquad[A]\end{array}$ & $\begin{array}{c}\text { Number } \\
\text { ofMaturityLevel } \\
\text { Statements } \\
{[B]}\end{array}$ & $\begin{array}{c}\text { MaturityLevel } \\
\text { Compliance Value } \\
{[A / B]=[C]}\end{array}$ & $\begin{array}{c}\text { NormalizedCompliance } \\
\text { Values } \\
{[\text { C/sum } C]=[D]}\end{array}$ & $\begin{array}{c}\text { Contribution } \\
{[M] x[D]}\end{array}$ \\
\hline 0 & 0.33 & 1.00 & 0.33 & 0.13 & 0.00 \\
\hline 1 & 0.66 & 2.00 & 0.33 & 0.13 & 0.13 \\
\hline 2 & 0.66 & 1.00 & 0.66 & 0.25 & 0.50 \\
\hline 3 & 0.00 & 0.00 & 0.00 & 0.00 & 0.00 \\
\hline 4 & 1.32 & 2.00 & 0.66 & 0.25 & 1.00 \\
\hline \multirow[t]{2}{*}{5} & 1.32 & 2.00 & 0.66 & 0.25 & 1.25 \\
\hline & & & 2.64 & 1.00 & 2.88 \\
\hline
\end{tabular}

Tabel 11. Hasil Perhitungan DS7 untuk Maturity Level 0-5

\begin{tabular}{|c|c|c|c|c|c|}
\hline $\begin{array}{c}\text { Maturity } \\
\text { Level } \\
{[M]}\end{array}$ & $\begin{array}{c}\text { Sum of Statements } \\
\text { ComplianceValues } \\
{[A]}\end{array}$ & $\begin{array}{c}\text { Number } \\
\text { ofMaturityLevel } \\
\text { Statements } \\
{[B]}\end{array}$ & $\begin{array}{c}\text { MaturityLevel } \\
\text { ComplianceValue } \\
{[A / B]=[C]}\end{array}$ & $\begin{array}{c}\text { NormalizedCompliance } \\
\text { Values } \\
{[C / \text { sum } C]=[D]}\end{array}$ & $\begin{array}{c}\text { Contribution } \\
{[M] x[D]}\end{array}$ \\
\hline 0 & 0.33 & 1.00 & 0.33 & 0.13 & 0.00 \\
\hline 1 & 1.65 & 3.00 & 0.55 & 0.22 & 0.22 \\
\hline 2 & 0.33 & 1.00 & 0.33 & 0.13 & 0.26 \\
\hline 3 & 0.00 & 0.00 & 0.00 & 0.00 & 0.00 \\
\hline 4 & 0.66 & 1.00 & 0.66 & 0.26 & 1.04 \\
\hline \multirow[t]{2}{*}{5} & 1.32 & 2.00 & 0.66 & 0.26 & 1.30 \\
\hline & & & 2.53 & 1.00 & 2.83 \\
\hline
\end{tabular}

Tabel 12. Hasil Perhitungan DS8 untuk Maturity Level 0-5

\begin{tabular}{|c|c|c|c|c|c|}
\hline $\begin{array}{l}\text { Maturity } \\
\text { Level } \\
{[M]}\end{array}$ & $\begin{array}{c}\text { Sum of Statements } \\
\text { Compliance Values } \\
{[\text { [A] }}\end{array}$ & $\begin{array}{c}\text { Number } \\
\text { ofMaturityLevel } \\
\text { Statements } \\
{[B]}\end{array}$ & $\begin{array}{c}\text { MaturityLevel } \\
\text { Compliance Value } \\
{[A / B]=[C]}\end{array}$ & $\begin{array}{c}\text { NormalizedCompliance } \\
\text { Values } \\
{[\text { C/sum } C]=[D]}\end{array}$ & $\begin{array}{c}\text { Contribution } \\
{[M] x[D]}\end{array}$ \\
\hline 0 & 0.33 & 1.00 & 0.33 & 0.13 & 0.00 \\
\hline 1 & 1.65 & 3.00 & 0.55 & 0.22 & 0.22 \\
\hline 2 & 0.33 & 1.00 & 0.33 & 0.13 & 0.26 \\
\hline 3 & 0.00 & 0.00 & 0.00 & 0.00 & 0.00 \\
\hline 4 & 0.66 & 1.00 & 0.66 & 0.26 & 1.04 \\
\hline \multirow[t]{2}{*}{5} & 1.32 & 2.00 & 0.66 & 0.26 & 1.30 \\
\hline & & & 2.53 & 1.00 & 2.83 \\
\hline
\end{tabular}

Tabel 13. Hasil Perhitungan ME1 untuk Maturity Level 0-5

\begin{tabular}{|c|c|c|c|c|c|}
\hline $\begin{array}{l}\text { Maturity } \\
\text { Level } \\
{[M]}\end{array}$ & $\begin{array}{c}\text { Sum of Statements } \\
\text { Compliance Values } \\
\qquad[A]\end{array}$ & $\begin{array}{c}\text { Number } \\
\text { ofMaturityLevel } \\
\text { Statements } \\
{[B]}\end{array}$ & $\begin{array}{c}\text { MaturityLevel } \\
\text { Compliance Value } \\
{[A / B]=[C]}\end{array}$ & $\begin{array}{c}\text { NormalizedCompliance } \\
\text { Values } \\
{[\text { C/sum } C]=[D]}\end{array}$ & $\begin{array}{c}\text { Contribution } \\
{[M] x[D]}\end{array}$ \\
\hline
\end{tabular}




\begin{tabular}{|l|l|l|l|l|l|}
\hline 0 & 0.33 & 1.00 & 0.33 & 0.13 & 0.00 \\
\hline 1 & 0.66 & 2.00 & 0.33 & 0.13 & 0.13 \\
\hline 2 & 0.66 & 1.00 & 0.66 & 0.25 & 0.50 \\
\hline 3 & 0.00 & 0.00 & 0.00 & 0.00 & 0.00 \\
\hline 4 & 2.00 & 0.66 & 0.25 & 1.00 \\
\hline 5 & 2.00 & 0.66 & 0.25 & 1.25 \\
\hline \multicolumn{2}{|l|}{ Maturity level berada pada level 2, hal ini berarti proses telah dikembangkan tetapi belum ada prosedur standar yang diterapkan } \\
\hline
\end{tabular}

Tabel 14. Hasil Perhitungan ME2 untuk Maturity Level 0-5

\begin{tabular}{|c|c|c|c|c|c|}
\hline $\begin{array}{l}\text { Maturity } \\
\text { Level } \\
{[M]}\end{array}$ & $\begin{array}{c}\text { Sum of Statements } \\
\text { Compliance Values } \\
{[\text { [A] }}\end{array}$ & $\begin{array}{c}\text { Number } \\
\text { ofMaturityLevel } \\
\text { Statements } \\
{[B]}\end{array}$ & $\begin{array}{c}\text { MaturityLevel } \\
\text { ComplianceValue } \\
{[A / B]=[C]}\end{array}$ & $\begin{array}{c}\text { NormalizedCompliance } \\
\text { Values } \\
{[\text { C/sum } C]=[D]}\end{array}$ & $\begin{array}{c}\text { Contribution } \\
{[M] x[D]}\end{array}$ \\
\hline 0 & 0.66 & 2.00 & 0.33 & 0.13 & 0.00 \\
\hline 1 & 1.32 & 3.00 & 0.44 & 0.17 & 0.17 \\
\hline 2 & 0.66 & 1.00 & 0.66 & 0.26 & 0.52 \\
\hline 3 & 0.00 & 0.00 & 0.00 & 0.00 & 0.00 \\
\hline 4 & 1.65 & 3.00 & 0.55 & 0.21 & 0.86 \\
\hline 5 & 2.31 & 4.00 & 0.58 & 0.23 & 1.13 \\
\hline & & & 2.56 & 1.00 & 2.67 \\
\hline
\end{tabular}

Maturity level berada pada level 2, hal ini berarti proses telah dikembangkan tetapi belum ada prosedur standar yang diterapkan

Setelah dilakukan proses pengumpulan data dengan kuesioner, diperoleh hasil perhitungan untuk setiap proses yang terdapat pada customer perspective, dengan menetapkan targetnya sebesar 3.50, dari target yang telah ditetntukan diharapakan bagian manajemen dapat memenuhi target tersebut, berikut ini hasil perhitungan untuk nilai gap yang terjadi antara kondisi organisasi saat ini dengan target yang telah ditetapkan:

Tabel 15. Gap antara kondisi saat ini dengan target

\begin{tabular}{|c|c|c|c|}
\hline Kondisi sekarang & Rata-rata kuesioner & Target & Gap \\
\hline $\mathrm{PO} 4=2.65$ & \multirow{15}{*}{ Total Rata-rata : } & \multirow{3}{*}{3.50} & \multirow{3}{*}{ Gap pada PO adalah sebesar 0.70} \\
\hline $\mathrm{PO} 7=2.95$ & & & \\
\hline Rata-rata $\mathrm{PO}=2.80$ & & & \\
\hline $\mathrm{AI} 3=2.67$ & & \multirow{5}{*}{3.50} & \multirow{5}{*}{ Gap pada AI adalah sebesar 0.29} \\
\hline $\mathrm{AI} 4=3.35$ & & & \\
\hline $\mathrm{AI} 5=3.39$ & & & \\
\hline $\mathrm{AI} 6=3.45$ & & & \\
\hline Rata-rataAI $=3.21$ & & & \\
\hline DS6 $=2.88$ & & \multirow{4}{*}{3.50} & \multirow{4}{*}{ Gap pada DS adalah sebesar 0.66} \\
\hline DS7 $=2.83$ & & & \\
\hline DS8 $=2.83$ & & & \\
\hline Rata-rata DS $=2.84$ & & & \\
\hline ME1 = 2.88 & & \multirow{3}{*}{3.50} & \multirow{3}{*}{ Gap pada ME adalah sebesar 0.73} \\
\hline ME2 $=2.67$ & & & \\
\hline Rata-rata $\mathrm{ME}=2.77$ & & & \\
\hline Total Gap & & & 2.38 \\
\hline Rata-rata Gap & & & 0.59 \\
\hline
\end{tabular}

Berdasarkan tabel perhitungan diatas, maka dapat status dan target organisasi dapat digambarkan di gambar 3

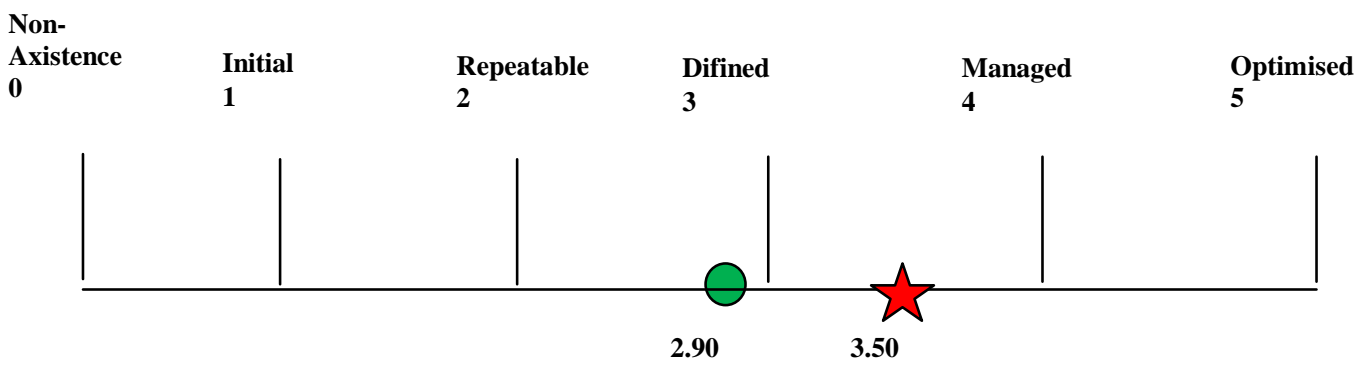

Gambar 3.status dan target organisasi 
Keterangan:

Status Organisasi saat ini
Target Organisasi gambar 4.

Penjelasan pada hasil perhitungan tabel 15 dengan menggunakan grafik dapat dilihat pada

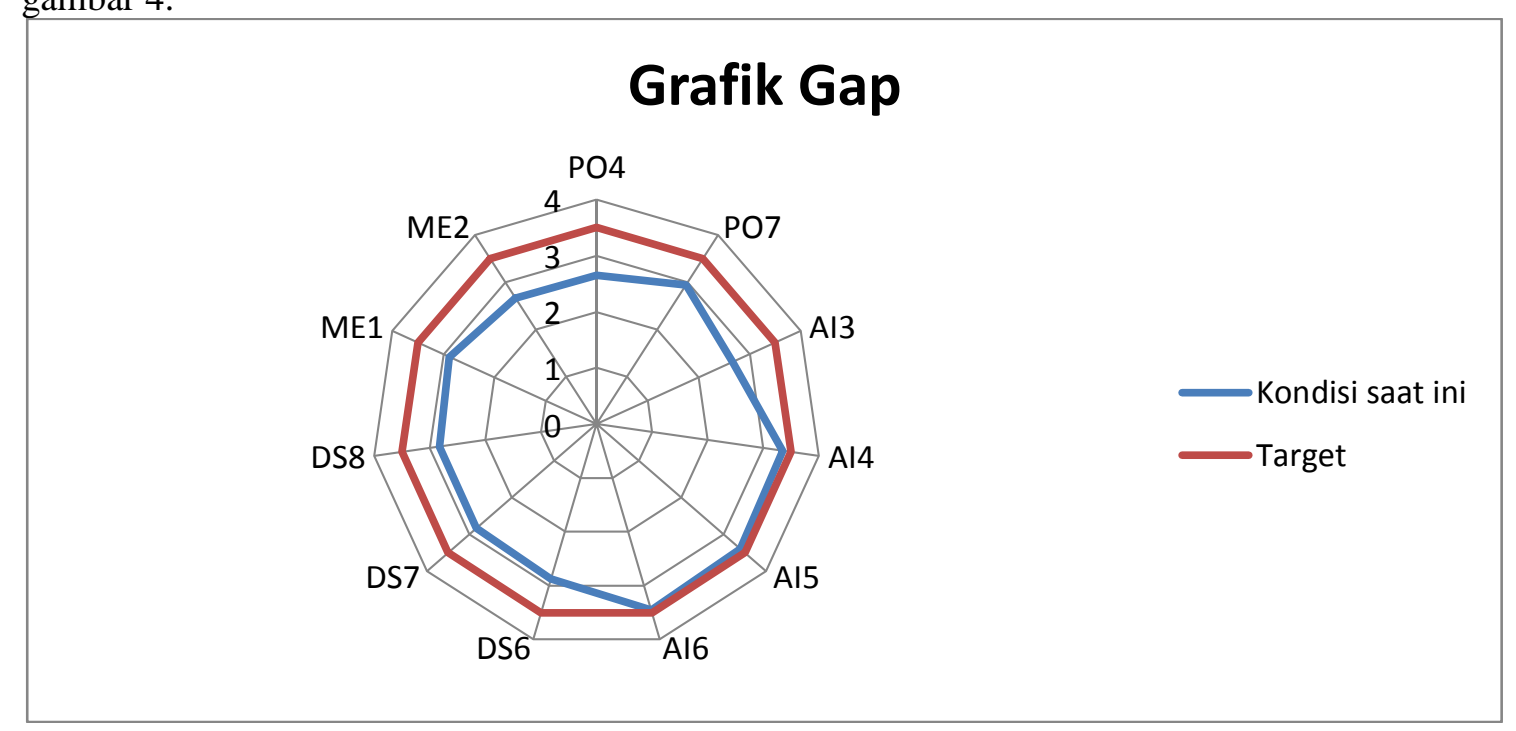

Gambar 4. Grafik kondisi dan target organisasi

Dalam melakukan pengisian tabel maturity model dan IT Goals, akan dilakukan proses perhitungan kematangan (maturity) pada masing-masing proses teknologi informasi. Gambar 4 merupakan hasil pengisian tabel maturity model dan IT Goals. Dari nilai-nilai diatas dapat diambil rata-rata, dengan perhitungan yang telah diolah, pada kuesioner untuk maturitylevel, maka diperoleh total $\mathrm{PO}=2.65+2.95=5.6$, dan memiliki rata-rata $\mathrm{PO}=2.8$, sehingga Gap $=0.70$. hal tersebut menunjukan bahwa perencanaan dan perorganisasian cukup baik.

Hasil perhitungan untuk Domain Plan and Organise (PO4) memperoleh nilai maturity level sebesar 2,65.atau dalam hal ini PO04 berada pada maturity level 2 yang berarti proses telah dikembangkan tetapi belum ada prosedur standar yang diterapkan, sehingga ada beberapa hal yang harus perlu diperhatikan. Pada perhitungan Domain Plan and Organise (PO7) ini, ada beberapa hal yang harus dicapai dengan cara mengikuti beberapa praktik pendukung yang telah ditetapkan seperti pengangkatan pegawaif, pelatihan, evaluasi kinerja, promosi dan pemutusan hubungan kerja. Sumber daya manusia dianggap merupakan asset yang sangat penting, dimana pengelolahan dan pengendalian bisnis internal tergantung pada kemampuan atau kompetensi pegawai maupun motivasinya. Hasil perhitungan untuk tahap ini memperoleh nilai maturity level sebesar 2,92 atau dalam hal ini PO07 berada pada maturity level 2 hal ini berarti proses telah dikembangkan tetapi belum ada prosedur standar yang diterapkan. Berdasarkan hasil perhitungan yang telah diolah, pada kuesioner untuk maturity level, maka diperoleh total $\mathrm{AI}=2.67+3.35+3.39+3.45=12.86$, dan memiliki rata-rata $\mathrm{AI}=3.21$, sehingga $\mathrm{Gap}=0.29$. hal tersebut menunjukan bahwa akurasi dan penerapan pada infarstruktur, sudah cukup baik.

Dalam tahap Domain Acquire and Implement (AI3) ini seharusnya suatu organisasi sudah memiliki proses-proses untuk memperolah dan mengimplementasikan suatu infrastuktur teknologi yang dimiliki, dengan cara melakukan perencanaan dalam memperoleh dan merawat infrastruktur agar sesuai dengan strategi teknologi dan pengembangan, guna untuk menjamin agar teknologi secara terus-menerus dapat mendukung aplikasi bisnis. Hasil perhitungan untuk tahap ini memperoleh nilai maturity level sebesar 2,67.atau dalam hal ini AI3 berada pada maturity level 2 hal ini berarti proses telah dikembangkan tetapi belum ada prosedur standar yang diterapkan.Dalam proses Domain Acquire and Implement (AI4) memerlukan dokumentasi dan manual standar yang digunakan oleh pengguna dan programmer TI, dengan melakukan training untuk menjamin kelangsungan aplikasi dan infrastruktur yang digunakan serta dijalankan dengan tepat. Maka dalam 
hal ini proses dokumentasi harus diperbaiki sesuai dengan kebutuhan bisnis yang berjalan. Hasil perhitungan untuk tahap ini memperoleh nilai maturity level sebesar 3,35 atau dalam hal ini AI4 berada pada maturity level 3 hal ini berarti prosedur telah distandarisasi, didokumentasikan, dan dikomunikasikan dan instansi telah mulai mengenai metodologi pengembangan sistem, namun belum adanya pengawasan dari pihak manajemen. Adanya penambahan dan perawatan darurat yang akan menghubungkan seluruh infrastruktur dan aplikasi dalam lingkungan produksi secara teratur, jelas dan sesuai aturan yang telah dikendalikan. Hasil perhitungan untuk tahap Domain Acquire and Implement (AI6) memperoleh nilai maturity level sebesar 3,45.atau dalam hal ini AI6 berada pada maturity level 3 hal ini berarti prosedur telah distandarisasi, didokumentasikan, dan dikomunikasikan dan instansi telah mulai mengenai metodologi pengembangan sistem, namun belum adanya pengawasan dari pihak manajemen.Berdasarkan hasil perhitung yang telah diolah, pada kuesioner untuk maturity level, maka diperoleh total $\mathrm{DS}=2.88+2.83+2.83=8.54$, dan memiliki rata-rata $\mathrm{DS}=2.84$, sehingga Gap $=0.66$. hal tersebut menunjukan bahwa perencanaan dan penjaminan keamanan, alokasi biaya, serta pelatihan SDM, sudah cukup baik.

Hasil perhitungan untuk tahap Domain Delivered and Support (DS5) memperoleh nilai maturity level sebesar 2,83 atau berada pada posisi Repeatable but Intuitive, yang artinya Proses prosedur yang ada telah dikembangkan sedemikian rupa sehingga juga diikuti oleh orang lain yang melakukan pekerjaan yang sama. Telah dimandatkan pula, bahwa prosedur ini wajib dipatuhi, namun bagaimanapun juga ada deviasi prosedur dalam pelaksanaannya yang belum diakomodasi.Prosedur itu sendiri masih belum memuaskan. Hasil perhitungan untuk tahapDomain Delivered and Support (DS6) diperoleh nilai maturity level sebesar 2,88 atau berada pada posisi Repeatable but Intuitive, yang artinya Proses prosedur yang ada telah dikembangkan sedemikian rupa sehingga juga diikuti oleh orang lain yang melakukan pekerjaan yang sama. Namun belum ada pelatihan formal atau prosedur standar komunikasi yang dipakai dan juga pertanggung jawaban masih bersifat individual.Pada level ini, terdapat ketergantungan terhadap keahlian individual sehingga terjadinya kesalahan masih besar kemungkinan terjadi.Dalam hal ini DS6 berada pada maturity level 2, sehingga ada beberapa hal yang harus perlu diperhatikan. Hasil perhitungan untuk tahap Domain Delivered and Support (DS7) diperoleh nilai maturity level sebesar 2,83 atau hal ini berarti proses telah dikembangkan tetapi belum ada prosedur standar yang diterapkan. Telah dimandatkan pula, bahwa prosedur ini wajib dipatuhi, namun bagaimanapun juga ada deviasi prosedur dalam pelaksanaannya yang belum diakomodasi.Prosedur itu sendiri masih belum memuaskan.Prosedur kerja telah distandarisasi dan didokumentasikan serta dikomunikasikan melalui proses-proses pelatihan.Telah dimandatkan pula, bahwa prosedur ini wajib dipatuhi, namun bagaimanapun juga ada deviasi prosedur dalam pelaksanaannya yang belum diakomodasi.Prosedur itu sendiri masih belum memuaskan. Sebab dengan adanya program pelatihan yang effektif akan dapat meningkatkan efektivitas dari pengguna teknologi dan mengurangi kesalahan yang terjadi pada pengguna, meningkatkan produktifitas dan meningkatkan pemenuhan pada proses pengendalian. Hasil perhitungan untuk tahap Delivered and Support (DS8) diperoleh nilai maturity level sebesar 2,83 atau hal ini berarti proses telah dikembangkan tetapi belum ada prosedur standar yang diterapkan. Prosedur kerja telah distandarisasi dan didokumentasikan serta dikomunikasikan melalui proses-proses pelatihan.Telah dimandatkan pula, bahwa prosedur ini wajib dipatuhi, namun bagaimanapun juga ada deviasi prosedur dalam pelaksanaannya yang belum diakomodasi.Prosedur itu sendiri masih belum memuaskan. Berdasarkan hasil perhitungan yang telah diolah, pada kuesioner untuk maturity level, maka diperoleh total $\mathrm{ME}=2.88+2.67=5.55$, dan memiliki ratarata $\mathrm{ME}=2.77$, sehingga $\mathrm{Gap}=0.73$. hal tersebut menunjukan bahwa perencanaan dalam pengawasan dan mengevaluasi kinerja internal IT sudah cukup baik.

Hasil perhitungan untuk tahap Domain Monitor and Evalute (ME1) diperoleh nilai maturity level sebesar 2,67 atau hal ini berarti proses telah dikembangkan tetapi belum ada prosedur standar yang diterapkan. Prosedur kerja telah distandarisasi dan didokumentasikan serta dikomunikasikan melalui proses-proses pelatihan.Telah dimandatkan pula, bahwa prosedur ini wajib dipatuhi, namun bagaimanapun juga ada deviasi prosedur dalam pelaksanaannya yang belum diakomodasi. Dalam proses ini menjelaskan tentang manajemen kinerja TI yang effektif dan memerlukan proses pengawasan, sehingga ada beberapa hal yang harus perlu diperhatikan. Hasil perhitungan untuk tahap Domain Monitor and Evalute (ME2) diperoleh nilai maturity level sebesar 2,67 atau hal ini berarti proses telah dikembangkan tetapi belum ada prosedur standar yang 
diterapkan. Pada proses memantau serta mengevaluasi kontrol internal yaitu Managed and Measurable. sehingga ada beberapa hal yang harus perlu diperhatikan.

\section{KESIMPULAN}

Kesimpulan dari penelitian ini adalah :

1. Dari hasil analisa menggunakan diagram fishbone didapatkan fakta bahwa dalam penyelenggaraan pendidikan kesetaraan di SKB Gunungkidul ditemukan ada enam masalah utama yaitu pendaftaran warga belajar, model pengajaran dan bahan ajar yang digunakan (meliputi metode pembelajaran, pengembangan kurikulum, dan penggunaan media belajar yang bisa digunakan oleh warga belajar), penyelenggara pendidikan, model pembelajaran, model evaluasi, dan evaluasi mutu.

2. Evaluasi pengendalian sistem informasi e-learning sesuai dengan standar COBIT dan empat domain yang ada di dalamnya, yaitu Plan and Organise (PO), Acquire and Implement (AI), Deliver and Support(DS) dan Monitor and Evaluate (ME).

3. Perhitungan kematangan (maturity) pada masing-masing proses teknologi informasi didapatkan suatu nilai total PO sebesar 5.6, dan memiliki rata-rata PO sebesar 2.8, sehingga Gap yang didapatkan sebesar 0.70 . hal tersebut menunjukan bahwa perencanaan dan perorganisasian cukup baik.

\section{DAFTAR PUSTAKA}

[1] M.E. Kamsori, "Penyuluhan Dan Pembinaan Wajar Dikdas 9 Tahun Sebagai Upaya Peningkatan Mutu Pendidikan Dalam Kerangka Peningkatan Ipm Jawa Barat", Proceeding FPTK, tahun 7, nomor 7, Oktober 2007.

[2] Desmawati ,"Penerapan Model Pendidikan Kecakapan Hidup Pada Program Pendidikan Kesetaraan Di Kota Semarang", Jurnal Edukasi, No. 1, 2011.

[3] C.M. Hung, C.H Chiu, Y.T Chen, M.J. Su, H.S Chen, "Effectiveness of Game-based Learning of a National Health e-Learning Network for nutrition education in elementary school", 11th International Conference on e-Health Networking, Applications and Services, 2009.

[4] A.G. Almekhlafi. "An Evaluation Study of an e-Learning Course at the United Arab Emirates University: A Case Study", Proceedings of the 2009 International Conference on Future Computer and Communication, pages 437-442

[5] B.Rienties, L.Toetenel, A.Bryan, "Scaling up" learning design: impact of learning design activities on LMS behavior and performance, Proceedings of the Fifth International Conference on Learning Analytics And Knowledge, pages 315-319

[6] S.Zheng, M.B.Rosson, P.C.Shih, J.M.Carroll, Understanding Student Motivation, Behaviors and Perceptions in MOOCs, Proceedings of the 18th ACM Conference on Computer Supported Cooperative Work \& Social Computing, pages 1882-1895. 